\title{
The Influence of Environmental Salinity on Hemocyanin Function in the Blue Crab, Callinectes sapidus
}

\author{
Alan Lawson Weiland \\ College of William \& Mary - Arts \& Sciences
}

Follow this and additional works at: https://scholarworks.wm.edu/etd

Part of the Marine Biology Commons, Oceanography Commons, and the Physiology Commons

\section{Recommended Citation}

Weiland, Alan Lawson, "The Influence of Environmental Salinity on Hemocyanin Function in the Blue Crab, Callinectes sapidus" (1976). Dissertations, Theses, and Masters Projects. Paper 1539624930.

https://dx.doi.org/doi:10.21220/s2-kw6p-nk21

This Thesis is brought to you for free and open access by the Theses, Dissertations, \& Master Projects at W\&M ScholarWorks. It has been accepted for inclusion in Dissertations, Theses, and Masters Projects by an authorized administrator of W\&M ScholarWorks. For more information, please contact scholarworks@wm.edu. 
THE INFLUENCE OF ENVIRONMENTAL SALINITY ON in

HEMOCYANIN FUNCTION IN THE BLUE CRAB,

CALLINECTES SAPIDUS

A Thesis
Presented to

The Faculty of the Department of Biology

The College of Willian and Mary in Virginia

In Partial Fulfillment

of the Requirements for the Degree of

Master of Arts

by

Alan Lawson We1land

1976 
APPROVAL SHEET

This thesis is submitted in partial fulfillment of the requirements for the degree of

Master of Arts

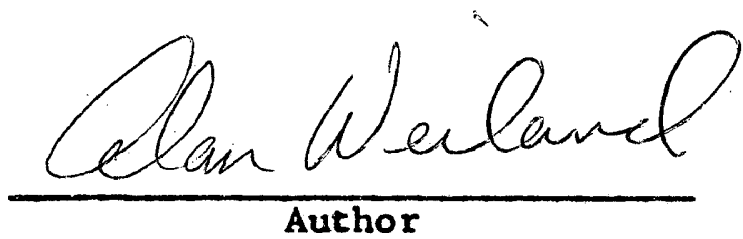

Approved, April 1976

$\frac{\text { Choulots D. Denerguin }}{\text { Chariot te P. Mangum }}$

Robert 2 B Bank

Robert E. L. Black

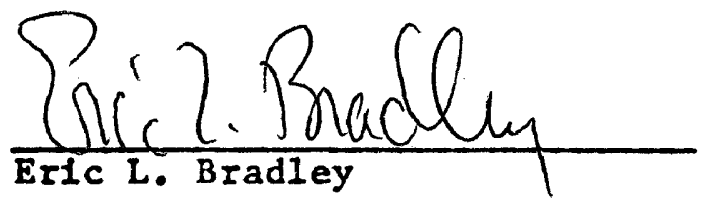

11 
TABLE OF CONTENTS

$\underline{\text { Page }}$

ACKNOWLEDGEMENTS . . . . . . . . . . . . . . . . IV IIST OF TABLES. . . . . . ................ . v LIST OF FIGURES . . . . . . . . . . . . . . . . . . vi vi ABSTRACT. ........................ vil INTRODUCTION. . . .................. 2 MATERIALS AND METHODS ................... 4 RESULTS ............................ 7 DISCUSSION. . . . . . . . . . . . . . . . . . 19 REFERENCES. . . . . . . . . . . . . . . . . . 28

651791 


\section{ACKNOWLEDGEMENTS}

The author wishes to express his appreciation to Dr. Charlotte P. Mangum, under whose gifldance this Investigation was conducted, for her patient guidance and criticism throughout the investigation. Thanks are due to Dr. Robert Black and Dr. Eric Bradley for their careful reading and criticism of the manuscript. Special thanks go to Mr. Glen Bean for his generous help in constructing apparatus and keeping it functioning during the experiments. 


\section{LIST OF TABLES}

Table $\quad$ Page

I. Results of Statistical Analysis. .......... 9

II. Table of all Data Collected. . . . . . . . . 21 


\section{LIST OF FIGURES}

Flgure

Page

1. The relationship of environmental salinity

to osmolality and chlorosity of crab

hemolymph. . . . . . . . . . . . ... 8 


\begin{abstract}
The blood PH of blue crabs is significantly lower when acclimated at $35 \%$ salinity than at $25 \%, 15 \%, 100$, or $5 \%$. The pattern of $\mathrm{PH}$ change closely resembles that of blood osmolality and chloride. There is a large increase in $\mathrm{PH}$ and a concomitant decrease in blood osmolality and chloride between $35 \%$ and $25 \%$, followed by smaller changes at lower acclimation salinities that were generally not signif1cant.

The blood oxygen parameters indicate little significant change in oxygen affinity over the salinity range. The PH increase at the lower salinities apparently countere the effect of the lower fonic concentration on hemocyanin affinity. The compensation is not perfect, but the two factors seem to balance each other well enough so that the resp1ratory parameters remain within a relatively narrow range.

The increase in blood $\mathrm{PH}$ at lower salinities may be the result of the input of ammonia produced in deamination of the intracellular pool of free amino acids as the cells conform to osmotic changes in body fluids.
\end{abstract}




\section{INTRODUCTION}

The effects of various fons on in vitro oxygen equilibrium properties of invertebrate respiratory pigments have been intensively studied in recent years. The responses of different oxygen carrying pigments to salt vary in magnitude and direction. In the case of crustacean hemocyanin the oxygen affinity increases as the concentration of inorganic salts increases. (Spock, 1967; Larimer and Riggs, 1964; Pickett et. al., 1966).

Recent work indicates that differences in Ionic concentration found In vivo in the hemolymph of the crab Carcinus meanas acclimated to different salinities are large enough to significantly alter oxygen affintty of buffered blood samples (Truchot, 1973).

Environmental salinity has also been found to affect blood PH In two crustaceans. As salinity is lowered the PH of the blood increases In Carcinus meanas. The $\mathrm{PH}$ change is independent of $\mathrm{PCO}_{2}$ and the mechanism of the change is unknown (Truchot, 1973). Interestingly, the opposite trend was found for the barnacle Pollicipes polymerus (Fyhn et. al., 1972). In this species $\mathrm{PH}$ decreases with decreasing salinity as a result of the input of $\mathrm{CO}_{2}$ produced in aeroblc metabolism, which Increases in dilute media. An increase in aerobic metabolism in dilute media is the most common response among crustaceans although some species exhiblt the opposite response or none at all (Dehnel, 1961; Lance, 1964; Hagerman, 1970). 
It is clear that environmental salinity can affect oxygen binding. properties of crustacean hemocyanin in vitro. However, the effect of envirommental salinity on in vivo respiratory function where different factors are changling and interacting simultaneously is unknown.

Callinectes sapidus was chosen for this in vivo study because it is a remarkably euryhaline crustacean that lives in unstable estuarine habitats. The spectes is found in waters ranging from fresh to hypersaline (Hedgpeth, 1967; Mangum and Amende, 1972). The spectes 1s capable of maintaining a hyperosmotic blood but the mechanism is not powerful enough to insure true homeosmoticity resulting In significant changes in dilute media (Ballard and Abbot, 1969; Lynch et al., 1973). The consequences of these fontc changes for in vivo oxygen transport by hemocyanin were investigated in the present study. 


\section{MATERIALS AND METHODS}

Collection and acclimation of experimental animals

Freshly caught crabs from the Chesapeake Bay were purchased from commerclal sources during January, February, June and July. Only undamaged animals with no missing appendages were used. They were maintained in large volumes $(75-250$ 1) of aerated recirculating water and fed beef 1 ver every two days until three days before the experiments. The animals were all adult males in intermolt stage $C_{4}$, ranging In carapace length from 6.3 to $7.5 \mathrm{~cm}$ (mean $=6.88 \mathrm{cn} \pm 0.05 \mathrm{~S} . \mathrm{E}$. ; $n=82$ ). With one exception, the body weights of each group of experImental animals are homogeneous ( $>.05$ according to student $s \underline{t})$. The sumer animals acclimated to $5 \%$ salinity were somewhat lighter (171 gm wet weight) than the winter group acclimated to the same salinity (206 gm) despite a similar carapace length (weights differ significantly; $P<.05)$.

The crabs were allowed to acclimate for $7-12$ days to water of either $5,10,25$ or $35^{\circ} / 00$ salinity at $21-23^{\circ} \mathrm{C}$. Water $\left(19-34^{\circ} / 00\right.$ salinity) was collected from the York River estuary and Wachapreague Inlet in Virginia. Minor increases in salinity were made by dissolving artificlal sea salt (Dayno Sales Co.); dilutions were made with distilled water. Salinity was determined with glass hydrometers calibrated with Copenhagen Normal Water; chlorinity with a Buchler-Cotlove Chloridometer. 
Sampling

A single three ml sample of prebranchial blood was taken from each crab at the base of the fourth leg (Infrabranchial sinus) within 30 sec of removing the animal from water. The sample was infected under mineral ofl and centrifuged at high speed (Sorvall SS - 1) for 10 minutes to express the fluld from the clot. This procedure was necessary for measurement of the $\mathrm{PH}$ of a concentrated protein solution, which requires a liquid junction capillary electrode, but it introduced the possibility that any one of the respiratory parameters might be Influenced by the diffusion of gases into the sample at the blood011 interface. To test this possibility, a set of samples was halved and aliquots Injected under (1) air equilibrated o1l, and (2) o1l bubbled for 15 minutes with $\mathrm{N}_{2}$ gas. As concluded previous $1 y$ (Mangum and Shick, 1972) there is no perceptibie effect on $\mathrm{PH}$ by using an oll seal. In an earlier test at low temperature, $\left(2{ }^{\circ} \mathrm{C}\right)$, there was no change in $\mathrm{PO}_{2}$ of samples injected directly into the electrode chamber or first under oil (Fyhn and Mangum, unpublished). In two of three tests at $22{ }^{\circ} \mathrm{C}, \mathrm{PO}_{2}$ was decreased by $2.5-3.5 \mathrm{~mm} \mathrm{Hg}(14-20 \%)$, but in a third it was increased by $1.0 \mathrm{~mm} \mathrm{Hg}(7 \%)$. Members of the paired $\mathrm{PO}_{2}$ measurements obtained at $22^{\circ} \mathrm{C}$ without and with the use of deoxygenated ofl are homogeneous (Mann-Wh1tney $U$ test) with one another, and with the results for samples infected directly into the electrode chamber without exposure to oil ( $P>.05$, according to student's $t)$.

The fluid was then taken back into a hypodermic syringe, and 50 ul injected into the themostated cell of a Radlometer Blood Gas Analyzer $\mathrm{PO}_{2}$ electrode (E5046). Alfquots of the same sample were 
taken anaerobically into the cap1llary of the Ifquid junction PH electrode, and $\mathrm{PH}$ measured on at least three successive subsamples. $0.2 \mathrm{ml}$ aliquots were taken Into the extractor syringe of a scholander micro-gasometric analyzer which contained potassium ferricyanide to elicit the oxygen bound to hemocyanin, and the gas analyzed volumetrically (Hoffman and Mangum, 1970). Osmotic concentration of two $0.2 \mathrm{ml}$ allquots was determined with a Precision Instrument Co. Osmette freezing point osmometer. Chloride ion concentration was determined on at least two $0.1 \mathrm{ml}$ aliquots with a Buchler-Cotlove chloridometer.

\section{Data analysis}

Bartlett's test for homogeneity of variance was performed to determine if parametric statistical procedures could be used. In most cases the result was not significant and a normal distribution was assumed. These data were tested by analysis of rariance with oneway classification (ANOVA), with winter and summer data treated separately and acclimation salinities considered as treatments. If a signiffcant difference within the four treatments was indicated by ANOVA, the salinity pairs that differed significantly were Identified by the Student-Newman-Keuls test (SNK).

In the few cases when the distribution was not normal, non parametric tests were utilized. The Kruskal-Wallis $\mathrm{H}$ test was performed and the heterogeneous variables were Identifled by the Mann-Whitney $U$ test. Correlations between homogeneous parameters were described by I, and those between heterogeneous parameters by Spearman Rank. The criterion of significance is $P=.05$. 


\section{RESULTS}

Osmotic Response to Low Salinity

As salinity is lowered the pattern of changes in osmolality and chloride ion concentration is similar to that previously reported (Lynch et al., 1973). Blood chloride is hypoionic to the medium at $35 \%$, slightly hypolonic at $25 \%$ and then hyperionic and strongly but Imperfectly regulated down to $5 \%$ (Figure 1). Blood osmolality is hyperosmotic at $35 \%$ and approximately paralleled the medium down to $25 \%$. From $25 \%$ to $5 \%$ osmolality is also strongly but imperfectly regulated (Figure 1).

The osmotic and lonic parameters are consistently higher in winter than in sumier animals, in spite of acclimation to the same laboratory temperature. The difference is not always significant, however (Table I).

PH (Prebranchial)

The $\mathrm{PH}$ of both winter and summer animals at $35 \%$ is signif1cantly lower than the $\mathrm{PH}$ at the other salinities (Table II). Summer animals show no significant difference between $\mathrm{PH}$ values at $5 \%$, $15 \%$ or $25 \%$. Winter animals at $5 \%$ have significantly higher PH values than animals at $15 \%$. There are no other significant differences.

The pattern of $\mathrm{PH}$ change closely resembles that of blood osmolality and chloride (Figure 1). There is a large increase in $\mathrm{PH}$ and a 
Fig 1. The relationship of environmental salinity to osmolalfty and chlorosity of crab hemolymph. 


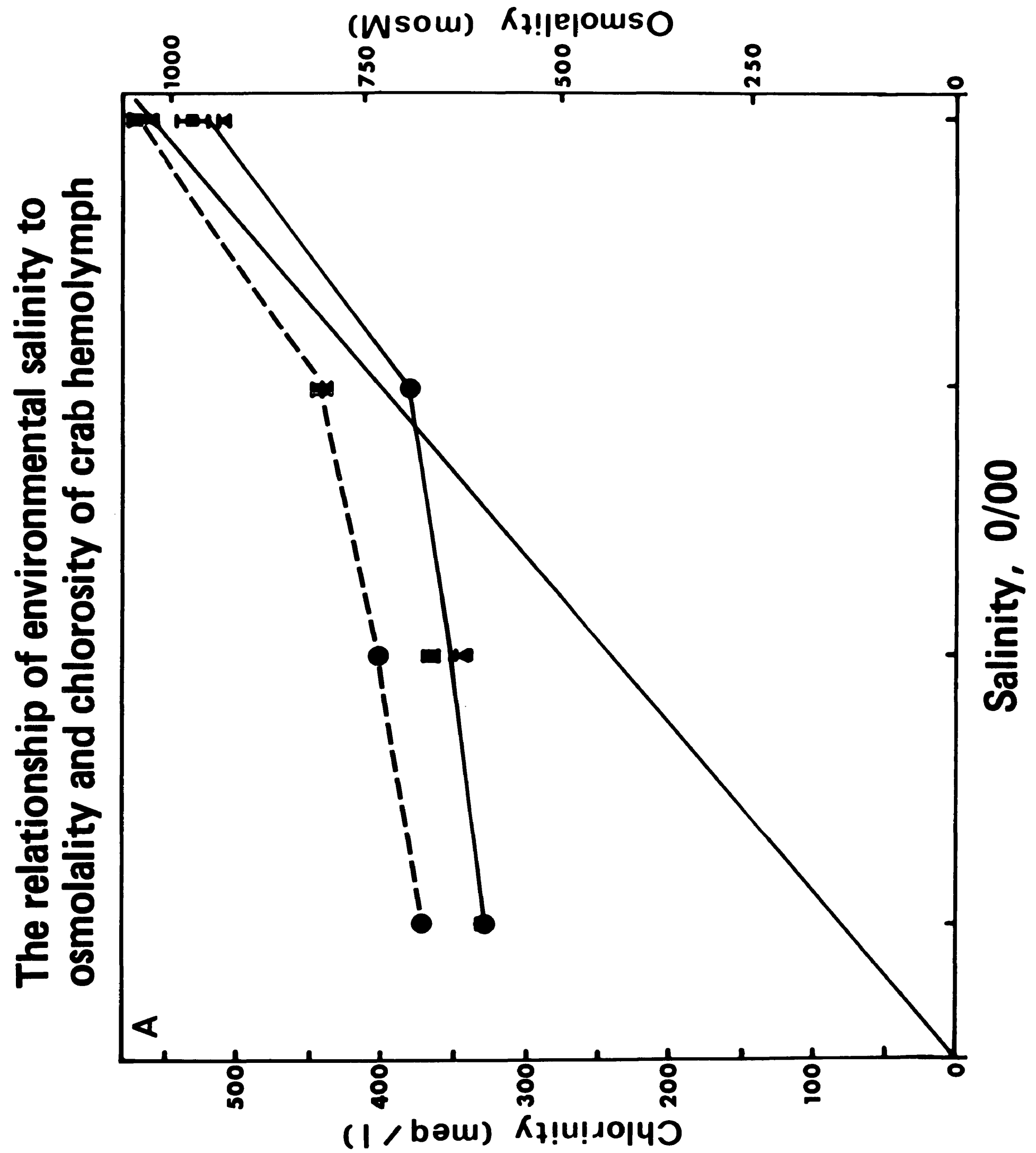




\section{Table I}

A.

PH

Summer Runs

1. Bartlett's test for homogenelty of varlance $=3.675<7.815, \mathrm{~N} . \mathrm{S}$.

2. Analysis of variance (Anova), one - way classification.

$F=8.94>4.50$, Significant at 0.01 level.

3. Student - Newman - Keuls test

Salinity Pairs

PH

$$
\begin{aligned}
& 35^{\circ} / 00-5^{\circ} / 00 \quad 0.0627>0.0481 \text { significant at } 0.01 \\
& 35 \%-25 \% \quad 0.0685>0.0550 \text { significant at } 0.01 \\
& 35 \%-15^{\circ} / 00 \quad 0.0832>0.0593 \text { significant at } 0.01 \\
& 25 \%-5 \% 00 \quad 0.0058<0.0366 \text { N.S. at } 0.05 \\
& 15 \%-5 \% 000205<0.0441 \text { N.S. at } 0.05 \\
& 15^{\circ} / 00-25^{\circ} / 00 \quad 0.0147<0.0366 \text { N.S. at } 0.05 \\
& 35^{\circ} / 00 \quad 5 \% \quad 25 \% \quad 15 \%
\end{aligned}
$$

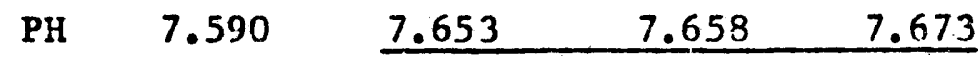

A Iine under the means indicates these do not deviate significantly at 0.05

\section{Winter Runs}

1. Bartlett's test $=0.494<7.815$ N.S.

2. Anova $F=14.05>4.30$ significant at 0.01

3. SNK Test 


\section{Table I $\left(\operatorname{con}^{\prime} t\right)$}

Salinity Pairs

$$
35 \% \text { - } 15 \% \text { \%0 }
$$$$
35 \%-25 \%
$$$$
35 \% \text { - 5\% }
$$$$
15 \% \text { - } 25 \%
$$$$
15 \% 00-5 \%
$$$$
5 \%-25 \%
$$$$
35 \%
$$

PH $\quad 7.489$
PH

$0.0770>0.0612$ significant at 0.01

$0.1040>0.0728$ Signfficant at 0.01

$0.1410>0.0762$ significant at 0.01

$0.0270<0.0470$ N.S. at 0.05

$0.0640>0.0550$ Significant at 0.05

$0.0370<0.0472$ N.S. at 0.05

$15 \%$

$25 \% \quad 5 \%$

7.566 7.630

A Ine under the means indicates these do not deviate significantly at 0.05 level.

A comparison of winter and summer $\mathrm{PH}$ values with Student's test.

\section{Salinity}

$5 \% 00$

$15 \%$

$25^{\circ} / 00$

$35 \%$
Winter PH Sumer PH

$7.630<7.653$

$7.566<7.673$

$7.593<7.658$

$7.488<$
Significance

N.S. at 0.05

Significant at 0.01

Significant at 0.01

Significant at 0.01 t value

$1.135<2.110$

$5.340>2.878$

$4.617>2.898$

$5.913>2.845$ 


\section{Table I $\left(\operatorname{con}^{\prime} t\right)$}

B.

Sumer Runs

$$
\underline{\mathrm{P}_{\mathrm{v}} \mathrm{O}_{2}}
$$

1. Bartlett's test $=1.390<7.815$ N.S.

2. Anova $F=3.47>2.92$ Significant at 0.05

3. SNK test

Salinity palrs

$$
\text { - } \mathbf{P}_{\dot{v}} \mathbf{O}_{2}
$$

\begin{tabular}{|c|c|c|}
\hline $35^{\circ} / 00-25^{\circ} / 00$ & $1.310<2.276$ & N.S. at 0.05 \\
\hline $35 \%$ & $2.430<2.749$ & N.S. \\
\hline $35^{\circ} / 00-15^{\circ} / 00$ & $3.410>3.064$ & Significant at 0.05 \\
\hline $5 \% / 00-25^{\circ} / 00$ & $1.120<2.330$ & N.S. \\
\hline $15^{\circ} / 00-25^{\circ} / 00$ & $2.100<2.814$ & N.S. \\
\hline $15 \%-5^{\circ} / 00$ & $0.980<2.331$ & N.S. \\
\hline $25^{\circ} / 00$ & $5 \% / 00$ & $15 \%$ \\
\hline $9.0 \mathrm{~mm} \mathrm{Hg} \quad 10.3$ & 11.4 & 12.4 \\
\hline
\end{tabular}

A Ine under the means indicates these do not deviate significantly at 0.05 .

Winter Runs

1. Bartlett's test $=11.725>7.815$ Significant 0.05

2. Non Parametric Kruskal - Wall1s H test. $\mathrm{H}=2.348$

N.S.

$25 \% \quad 35 \% \quad 35 \% \quad 5 \%$

\begin{tabular}{llll}
11.3 & 13.2 & 13.4 & 13.7 \\
\hline
\end{tabular}

A line under the means indicates these do not deviate significantly. 
Table I $\left(\operatorname{con}^{1} t\right)$

A comparison of winter and sumer. values with Student's test.

\begin{tabular}{|c|c|c|c|c|}
\hline Salinity & Winter $P_{\mathrm{v}}{ }_{2}$ & Summer $\mathrm{P}_{\mathrm{V}} \mathrm{O}_{2}$ & Significance & $t$ value \\
\hline $5^{\circ} / 00$ & $13.7 \mathrm{~mm} \mathrm{Hg}$ & 11.4 & N.S. at 0.0 .5 & $1.594<$ \\
\hline $15^{\circ} / 00$ & 13.2 & 12.4 & N.S. at 0.05 & $0.590<2.110$ \\
\hline $25^{\circ} / 00$ & 11.3 & 10.3 & N.S. at 0.05 & $1.156<2.110$ \\
\hline $35^{\circ} / 00$ & 13.4 & 9.0 & Sign. at 0.05 & $2.752>$ \\
\hline
\end{tabular}


Table I (con't)

c.

$$
\mathrm{c}_{\mathrm{v}} \mathrm{O}_{2}
$$

Summer Runs

1. Bartlett's test $1.261<7.815$ N.S.

2. Anova $F=4.231>2.922$ Significant at 0.05 .

3. SNK test

Salinity Pairs

$$
\begin{aligned}
& 25 \%-5 \% 000.1512>0.1290 \text { significant at } 0.05 \\
& 15 \%-5 \% 0.1684>0.1556 \text { significant at } 0.05 \\
& 35 \%-5 \% \text { 0.2070>000 } 0.1674 \text { significant at } 0.05 \\
& 15 \%-25 \% 0.0172<0.1290 \text { N.S. } \\
& 35 \%-25 \% 00.0558<0.1520 \text { N.S. } \\
& 15 \%-35 \% 00 \quad 0.0386<0.1260 \text { N.S. } \\
& 5 \% \quad 25 \% \quad 15 \% \quad 35 \% \\
& \begin{array}{lllll}
0.708 \text { Vol } \% & 0.557 & 0.539 & 0.501 \\
\hline
\end{array}
\end{aligned}
$$

A line under the means indicates these do not devlate significantly. Winter Runs

1. Bartlett's test $0.459<7.815$ N.S.

2. Anova $F=1.269<2.900$ N.S. at 0.05

\begin{tabular}{llll}
$15 \%$ & $35 \% 0$ & $5 \%$ & $25 \%$ \\
0.584 & 0.585 & 0.687 & 0.698 \\
\hline
\end{tabular}

A line under the means indicates these do not differ significantly. 


\section{Table I $\left(\operatorname{con}^{\prime} t\right)$}

Comparison of Winter and Summer values t test.

\begin{tabular}{|c|c|c|c|c|c|c|c|}
\hline Salinity & Winter & $\mathrm{C}_{\mathrm{v}} \mathrm{O}_{2}$ & & Sumer $\mathrm{C}_{\mathrm{v}} \mathrm{O}_{2}$ & Significance & \multicolumn{2}{|c|}{$t$ test } \\
\hline $5^{\circ} / 00$ & 0.687 & Vo1\% & $<$ & 0.708 & N.S. & $0.277<$ & 2.110 \\
\hline $15^{\circ} / 00$ & 0.584 & & $>$ & 0.539 & N.S. & $0.024<$ & 2.110 \\
\hline $25^{\circ} / 00$ & 0.698 & & $>$ & 0.557 & Sig. at 0.05 & $2.208>$ & 2.110 \\
\hline $35^{\circ} / 00$ & 0.585 & & $>$ & 0.501 & N.S. & $1.280<$ & 2.10 \\
\hline
\end{tabular}


Table I $\left(\operatorname{con}^{\prime} t\right)$

D.

Chlor1de

Summer Runs

1. Bartlett's test $=3.511<7.815$ N.S.

2. Anova $F=120.10>4.50$ significant at 0.01

3. SNR test

Salinity Pairs

\begin{tabular}{|c|c|c|c|}
\hline $25^{\circ} / 00-35^{\circ} / 00$ & 107.6 & $>22.3$ & SIgnificant \\
\hline $15^{\circ} / 00-35^{\circ} / 00$ & 129.6 & $>25.6$ & SIgniflcant \\
\hline $5^{\circ} / 00-35^{\circ} / 00$ & 167.3 & $>27.6$ & Stgnificant \\
\hline $15^{\circ} / 00-25^{\circ} / 00$ & 22.9 & $>22.8$ & Signiflcant \\
\hline $5^{\circ} / 00-25^{\circ} / 00$ & 59.8 & $>26.2$ & SIgnificant \\
\hline $5 \% / 00-15^{\circ} / 00$ & 37.7 & $>22.9$ & Significant \\
\hline
\end{tabular}

WInter Runs

1. Bartlett's test $=2.887<7.815$ N.S.

2. Anova $F=85.84>4.50 \quad$ Significant at 0.01

3. SNK Test

Salin1ty Pairs

$\begin{array}{lll}35^{\circ} / 00-25^{\circ} / 00 & 156.1>37.1 & \text { Significant at } 0.01 \\ 35^{\circ} / 00-15^{\circ} / 00 & 165.9>41.4 & \text { Significant at } 0.01 \\ 35^{\circ} / 00-5^{\circ} / 00 & 193.3>44.7 & \text { Significant at } 0.01 \\ 15^{\circ} / 00-25^{\circ} / 00 & 9.8<26.9 & \mathrm{~N} . \mathrm{S} . \\ 5^{\circ} / 00-25^{\circ} / 00 & 37.2>32.4 & \text { Significant at } 0.05 \\ 5^{\circ} / 00-15^{\circ} / 00 & 27.4>26.1 & \text { Significant at } 0.05\end{array}$


Table I (con't)

\begin{tabular}{|c|c|c|c|c|c|}
\hline \multicolumn{6}{|c|}{ Comparison of Winter and Summer Values } \\
\hline Salinity & $\begin{array}{c}\text { Winter } \\
\text { Chloride }\end{array}$ & & $\begin{array}{c}\text { Summer } \\
\text { Chlorlde }\end{array}$ & Significance & t test \\
\hline $5 \%$ & 336.7 & $>$ & 322.4 & N.S. & $1.340<2.101$ \\
\hline $15 \%$ & 364.1 & $>$ & 343.9 & Sig. at 0.05 & $2.102>2.101$ \\
\hline $25 \%$ & 373.9 & $<$ & 382.1 & N.S. & $0.846<2.101$ \\
\hline $35 \%$ & 530.0 & $>$ & 489.8 & Sig. at 0.01 & $3.170>2.878$ \\
\hline
\end{tabular}


Table I ( $\left.\operatorname{con}^{\prime} t\right)$

E. We1ghts

Summer Runs

1. Bartlett's test $=0.411<7.815$ N.S.

2. Anova $F=0.600<2.92$ N.S.

$5 \% \quad 25 \% \quad 15 \% \quad 35 \%$

\begin{tabular}{llll}
171.0 & 174.0 & 178.1 & 185.5 \\
\hline
\end{tabular}

A line under the means Indicates these do not deviate significantly at 0.05 .

Winter Runs

1. Bartlett's Test $=7.383<7.815$ N.S.

2. Anova $F=1.25<2.92$ N.S.

$25 \% \quad 25 \% \quad 35 \% \quad 5 \%$

\begin{tabular}{llll}
183.0 & 190.4 & 202.8 & 206.3 \\
\hline
\end{tabular}

A line under the means indicates these do not deviate significantly.

Comparison of Winter and Summer Welghts; t test.

$\begin{array}{llllll}\text { Salinity } & \text { Winter } & & \text { Summer } & \text { Significance } & \frac{t \text { test }}{2 \%} \\ 5 \% & 206.3> & 171.0 & \text { Sign. at } 0.01 & 3.36>2.88 \\ 15 \% & 183.0 & 178.1 & \text { N.S. } & 0.39<2.11 \\ 25 \% & 190.4>174.0 & \text { N.S. } & 1.36<2.11 \\ 35 \% & 202.8>185.5 & \text { N.S. } & 1.19<2.08\end{array}$


concomftant decrease in blood osmolality and chloride between $35 \%$ and $25 \%$, followed by smaller changes at lower acclimation sallnities that were generaily not significant. The inverse relationship of blood PH and the osmotfc parameters extends to the seasonal difference; winter animals, which have a more concentrated blood, also have a lower blood PH.

$\mathrm{P}_{v} \mathrm{O}_{2}$ (Prebranchial partial pressure of oxygen)

There is no significant change in $\mathrm{P}_{\mathrm{v}} \mathrm{O}_{2}$ when winter animals are acclimated to the four salinities. Summer animals at $15 \%$ have a signiflcantly higher $\mathrm{P}_{v} \mathrm{O}_{2}$ than those at $35 \%$ (see Table I). There are no other significant differences. Salintty appears to have little effect on $\mathrm{P}_{\mathrm{v}} \mathrm{O}_{2}$.

$\mathrm{C}_{\mathbf{v}} \mathrm{O}_{2}$ (Prebranchial total oxygen content in volume percent) For the winter animals the total oxygen concentration of prebranchlal blood including both dissolved and hemocyanin bound oxygen, does not change significantly at any acclimation salinity. The $\mathrm{C}_{\mathrm{v}} \mathrm{O}_{2}$ value of sumner animals at $5 \%$ is significantly higher than the values at the other salinities. There are no other differences (see Table I). Comparing winter and summer values, the only significant difference is at $25 \%$ 


\section{DISCUSSION}

\section{A Possible Explanation of PH Change}

wh th Acclimation Salinity

Fyhn et al ('72) suggested that intracellular osmolalicy in the gooseneck barnacle Poll1clpes polymerus is not malntalned by changes In free amino acids. Moreover, body fluid PH varies directly with acclimation salinity. This response results from the Input of $\mathrm{CO}_{2}$ produced in aerobic metabolism, which increases in dilute media.

$\mathrm{VO}_{2}$ of adult Callinectes sapldus does not change when acclimation salinity is reduced from 30 to $10 \%$ (Laird 73 ), and therefore It is unlikely that the accompanying increase in blood $\mathrm{PH}$ is due to a reduction in $\mathrm{PCO}_{2}$. It is more likely that the $\mathrm{PH}$ increase at low salinity results from an excess of base, an hypothesis suggested earlier for Carcinus meanas by Truchot ('73) although the effective base was not Identified.

Both Callinectes sapldus and Carcinus meanas are capable of extracellular osmotic regulation. The regulatory mechanisms in these specles can dampen the change in osmotic concentration of the blood when salinity is altered but nelther regulates perfectly enough to achleve homeosmoticity in dilute media. Extracellular regulation is accompanied by intraceliular regulation. In both species a pool of free amino acids participates in this intracellular regulation 
(Schoffeniels and Gilles, 1970; Gerard and G1lles, 1972; Slebers et al., 1972).

As salinfty decreases the amount of free amino actis in the tissues decreases and at the same time the ammonta concentration in the hemolymph Increases in both species (Gerard and Gilles, 1972; Siebers et al., 1972). These events are thought to result from increased deamination of the free amino actds (Gerard and Giles, 1972). Blue crabs in $50 \%$ seawater have considerably higher (10x) amonia levels than those in undiluted seawater. Specifically, ammonfa Increases by $1.2-1.3 \times 10^{-4} \mathrm{M} / 1$, a quantity which could cause the observed PH Increase (see Table II). In Carcinus meanas transferred from 38 to $11 \%$ salinity the ammonia increase is even greater $\left(7 \times 10^{-4} \mathrm{M} / 1\right.$; Siebers et al., 1972), which could also cause the greater blood $\mathrm{PH}$ change. In this species the ammonia concentration does not decrease significantly from the elevated value for at least 10 days following the exposure to a dilute salinity. The actual magnitude of the $\mathrm{PH}$ change induced by the addition of that quantity of base to the blood depends on Its bufferIng capacity, which is not known.

By far the greatest change in osmolality and chloride fon concentration in the blood is between $35 \%$ and $25^{\circ} \%$. Further reductions in salinity cause decreases in osmolailty and chloride ion concentration, but the amount of decrease is much less as shown in Figure 1. Assuming that the free amino acid pool is controlled, catabolically, the greatest increase in deamination and hence ammonia 
Table II

Values Determined and Animals Acclimated

at $22.0^{\circ} \mathrm{c} \pm{ }_{1}{ }^{\circ} \mathrm{c}$

Abbreviations

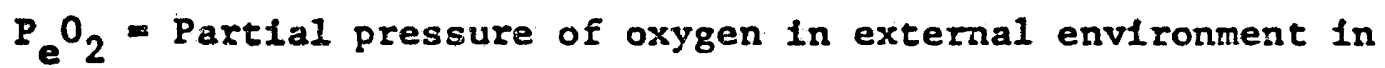
millimeters of mercury.

Wt. = Wet welght of animals in grams.

Cm. - Carapace length in centimeters.

$\mathrm{P}_{\mathbf{v}} \mathrm{O}_{2}=$ Prebranchial partial pressure of oxygen.

$\mathrm{C}_{\mathrm{v}} \mathrm{O}_{2}=$ Prebranchial oxygen content in Volume percent.

OSMO = Osmolality in Milliosmoles.

CL- - Chloride Ion concentration in milli-equivalents

per I1ter.

$\mathrm{C}_{\mathrm{c}^{0}} \mathrm{O}_{2}=$ oxygen carrying capacity in volume percent.

$S_{v}=$ Venous percent oxygen saturation. 
Table II $\left(\cos ^{\prime} t\right)$

Summer $5 \%$ Salinity

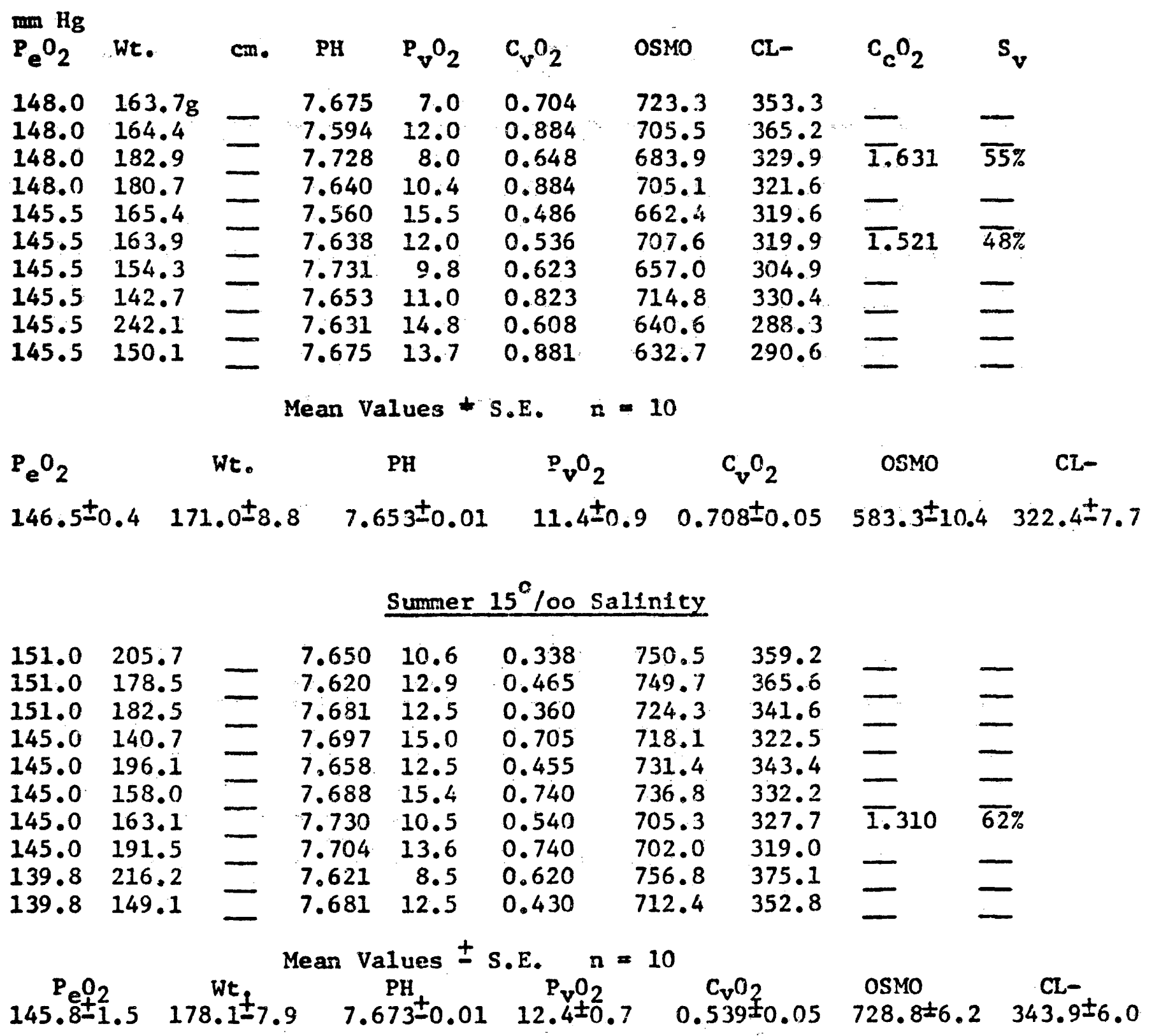


Table II $\left(\operatorname{con}^{\circ} t\right)$

Summer $25 \%$ Salinity

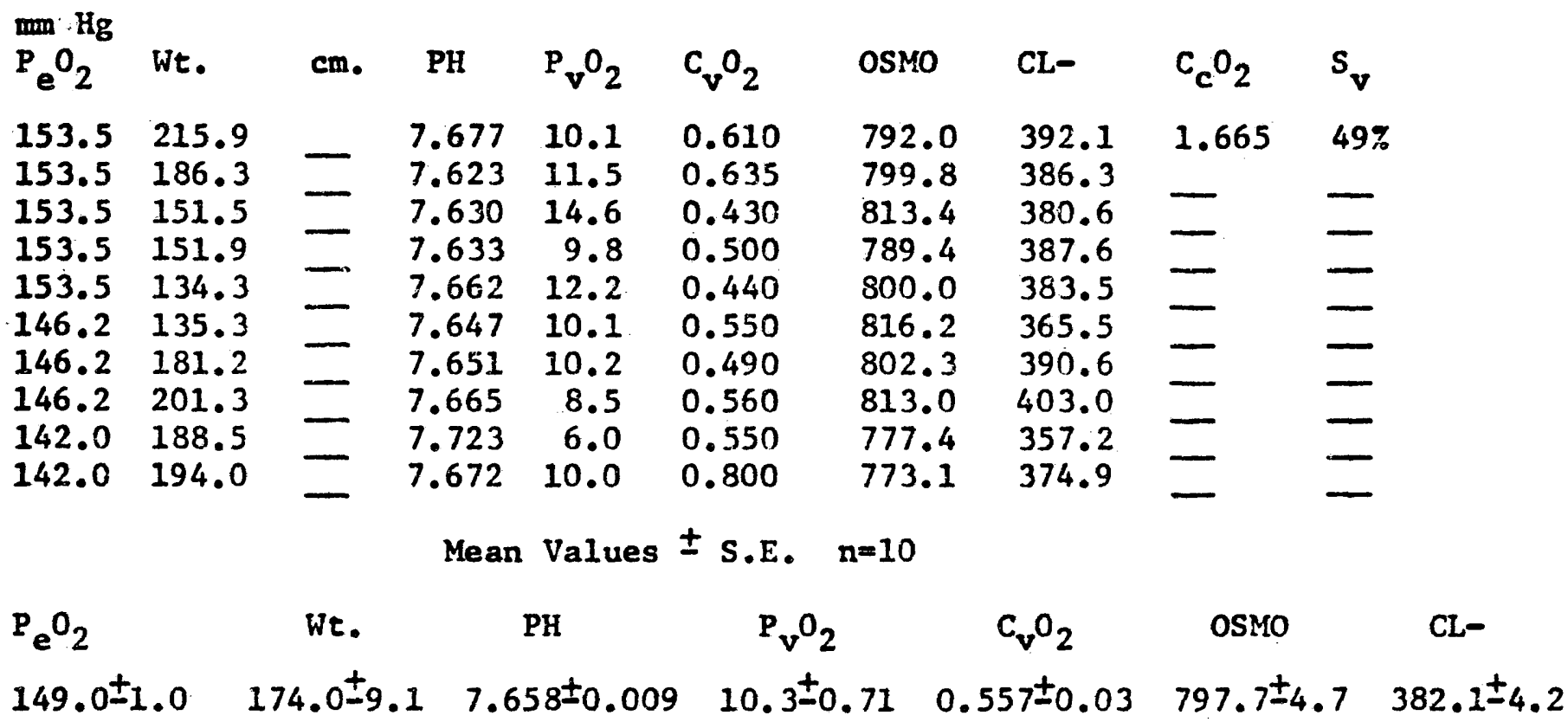

Surmer $35 \%$ Salinity

\begin{tabular}{lllllllllll}
141.6 & 236.8 & - & 7.613 & 5.6 & 0.433 & 968.0 & 500.8 & 1.371 & $48 \%$ \\
141.6 & 175.6 & - & 7.619 & 4.5 & 0.803 & 993.5 & 462.4 & 1.980 & $53 \%$ \\
141.6 & 183.3 & - & 7.654 & 11.5 & 0.526 & 959.1 & 507.7 & - & - \\
141.6 & 179.1 & - & 7.640 & 11.6 & 0.401 & 1065.7 & 497.5 & - & - \\
141.6 & 200.5 & - & 7.615 & 7.4 & 0.405 & 971.9 & 473.1 & - & - \\
150.0 & 172.9 \\
150.0 & 216.0 & - & - & 7.578 & 8.7 & 0.765 & 999.0 & 468.8 & - & - \\
150.0 & 156.0 & 7.573 & 5.5 & 0.380 & 1082.9 & 506.5 & - & - \\
150.0 & 175.7 \\
150.0 & 184.2 & - & - & -526 & 11.1 & 0.420 & 992.1 & 502.8 & - & - \\
150.0 & 160.6 & 7.533 & 11.5 & 0.430 & 999.4 & 491.6 & - & - \\
\hline & 7.578 & 13.0 & 0.430 & 1002.9 & 480.0 & - & -
\end{tabular}

Mean Values \pm S.E. $n=11$

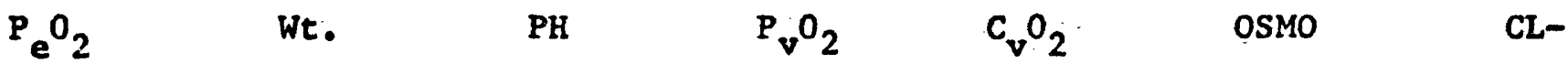

$146.2_{1.3}^{ \pm} 185.5_{7.2} \quad 7.590 \pm_{0.010} \quad 9.0 \pm 0.9 \quad 0.501 \pm_{0.04} \quad 1004.8 \pm 11.6 \quad 489.8 \pm 4.8$ 
Table II ( $\left.\operatorname{con}^{\prime} t\right)$

\section{Winter $5 \%$ Salinity}

$\mathrm{Hg}$

\begin{tabular}{|c|c|c|c|c|c|c|c|c|}
\hline $\mathrm{P}_{\mathrm{e}} \mathrm{O}_{2}$ & Wt. & cm. & PH & $\mathrm{P}_{v} \mathrm{O}_{2}$ & $\mathrm{C}_{\mathbf{v}} \mathrm{O}_{2}$ & OSMO & CL- & $\mathrm{C}_{\mathrm{c}} \mathrm{O}_{2}$ \\
\hline $\begin{array}{l}157.2 \\
147.1 \\
154.1 \\
154.1 \\
159.7 \\
154.0 \\
154.0 \\
152.0 \\
152.0 \\
152.0\end{array}$ & $\begin{array}{l}209.9 \\
224.0 \\
215.5 \\
202.1 \\
195.7 \\
230.0 \\
175.2 \\
215.5 \\
180.0 \\
215.5\end{array}$ & $\begin{array}{l}7.4 \\
7.5 \\
7.0 \\
7.5 \\
6.9 \\
6.8 \\
6.6 \\
6.8 \\
6.5 \\
6.8\end{array}$ & $\begin{array}{l}7.584 \\
7.688 \\
7.567 \\
7.634 \\
7.690 \\
7.642 \\
7.580 \\
7.603 \\
7.663 \\
7.647\end{array}$ & $\begin{array}{r}8.3 \\
9.5 \\
18.1 \\
19.2 \\
13.2 \\
16.1 \\
15.9 \\
13.4 \\
9.9 \\
13.8\end{array}$ & $\begin{array}{l}0.700 \\
0.976 \\
0.945 \\
0.766 \\
0.669 \\
0.450 \\
0.600 \\
0.403 \\
0.630 \\
0.731\end{array}$ & $\begin{array}{l}685.8 \\
669.6 \\
661.4 \\
648.4 \\
704.8 \\
657.0 \\
658.6 \\
692.8 \\
679.8 \\
716.9\end{array}$ & $\begin{array}{l}327.1 \\
328.8 \\
326.5 \\
328.3 \\
377.6 \\
312.5 \\
308.1 \\
359.4 \\
331.6 \\
366.8\end{array}$ & $\begin{array}{l}- \\
- \\
- \\
-\end{array}$ \\
\hline
\end{tabular}

$\mathrm{P}_{\mathrm{e}} \mathrm{O}_{2} \quad$ Wt. $\mathrm{PH} \quad \mathrm{P}_{\mathrm{V}}^{\mathrm{O}} \quad \mathrm{C}_{\mathrm{v}} \mathrm{O}_{2}$ OSMO $\quad \mathrm{CL}-$

$\begin{array}{llllllll}153.6 \pm 1.0 & 206.3 \pm 5.7 & 7.630 \pm 0.01 & 13.7 \pm 62 & 0.687 \pm 0.06 & 677.5 \pm 7.1 & 336.7 \pm 7.3\end{array}$

Winter $15^{\circ} / 00$ Salinity.

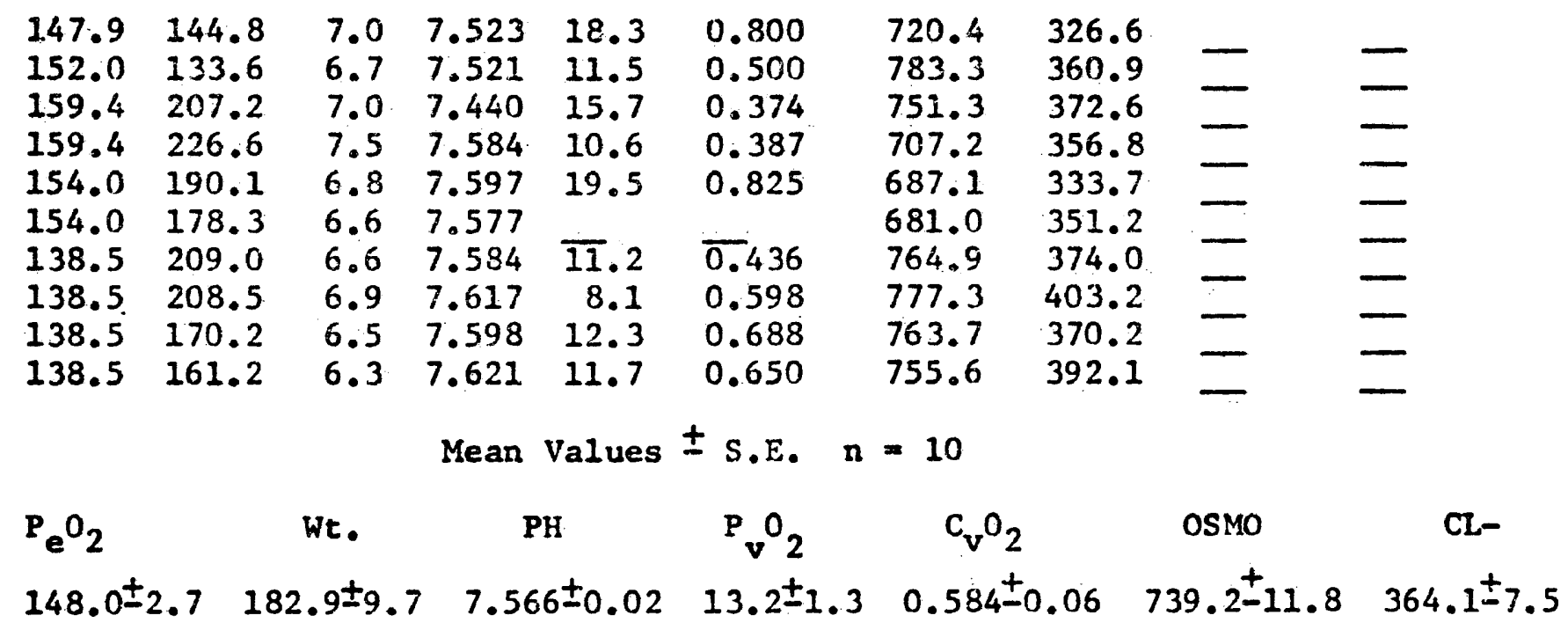


Table II $\left(\operatorname{con}^{\prime} t\right)$

Winter $25 \%$ Salinity

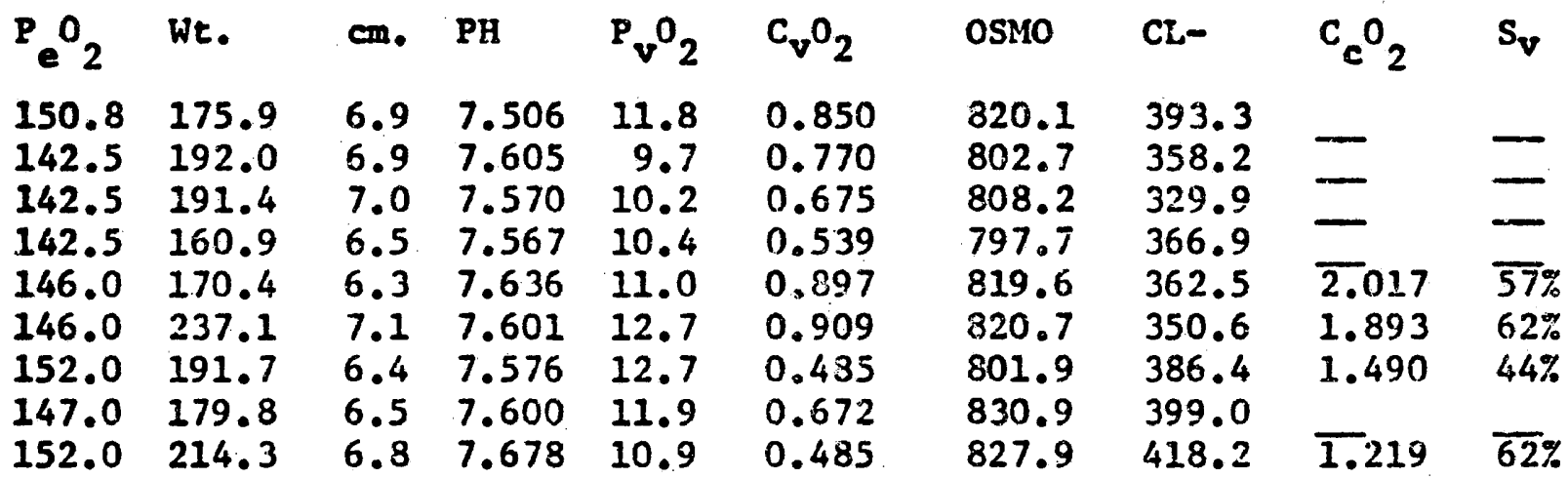

Mean Values \pm S.E. $n=10$

$\mathrm{P}_{\mathrm{e}} \mathrm{O}_{2} \quad$ Wt. $\quad \mathrm{PH} \quad \mathrm{P}_{\mathrm{v}} \mathrm{O}_{2} \quad \mathrm{C}_{\mathrm{v}} \mathrm{O}_{2} \quad$ OSMO $\quad \mathrm{CL}$ -

$146.8 \pm_{1.3} \quad 190.4 \pm 7.8 \quad 7.593 \pm_{0.01} \quad 11.3 \pm 0.4 \quad 0.698 \pm 0.06 \quad 814.4 \pm 4.0 \quad 373.9 \pm 9.2$

\section{Winter $35^{\circ} / 00$ Salinity}

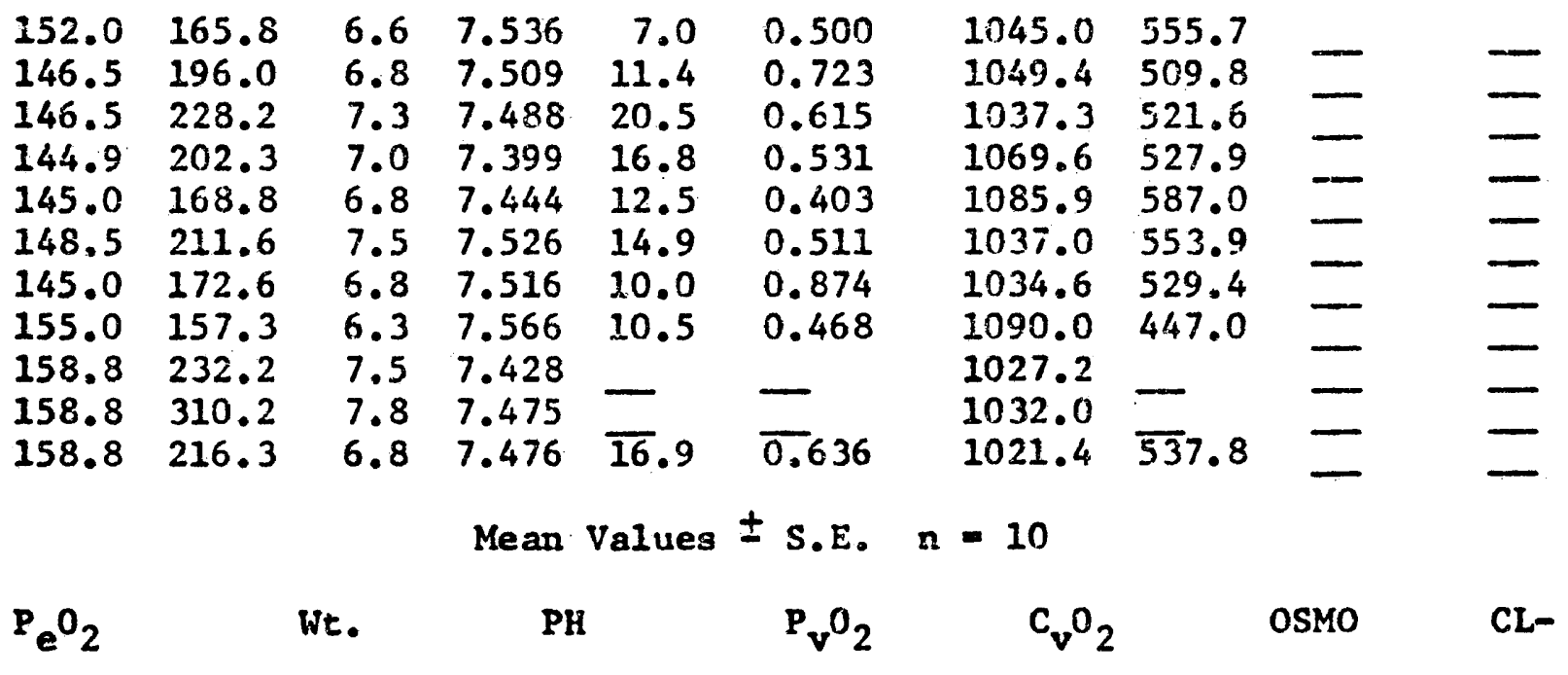

$149.1 \pm_{1.6} \quad 202.8 \pm_{12.2} \quad 7.488 \pm .01 \quad 13.4 \pm 1.4 \quad 0.5845 \pm 0.05 \quad 1044.3 \pm 7.5 \quad 530.0 \pm 12.9$ 
concentration would be expected between $35 \%$ and $25 \%$ with little Increase in ammonia output between $25^{\circ} / 00$ and the lower salinities. It is interesting that significant differences in $P H$ are found only between $35 \%$ and the three lower salinities. In fact the correlations of $\mathrm{PH}$ with both osmolal1ty $(\mathrm{P}<.01)$ and chlorfde $(\mathrm{P}<.001)$ are highly signfficant.

\section{Effects of Acclimation Salinity on Oxygen Transport}

When the blue crab makes osmotic adfustments to dilute media, blood PH rises. If this change were unopposed, it would result in an Increase in oxygen affintty and thus \% oxyhemocyanin. At the same time, however, the salt content of the blood decreases. If this change occurred in isolation, the result would be a reduction in hemocyanin oxygenation.

Another variable that must be considered is oxygen consumption $\left(\mathrm{VO}_{2}\right)$. Although $\mathrm{yO}_{2}$ changes as salinity changes in many crustaceans, Laird found that Callinectes sapidus exhibits no $\dot{\mathrm{V}}_{2}$ change at acclimation salinities between $30 \%$ and $10 \%$ ( $\left.25^{\circ} \mathrm{c}\right)$. However, Mangum (1976) found that $\mathrm{VO}_{2}$ does increase at $5 \%$.

The blood oxygen parameters indicate little significant change In oxygen affinity over the salinity range (see Table I). The PH Increase at the lower salinities apparently counters the effect of the lower lonic concentration on hemocyanin affinity. The compensation Is not perfect, but the two factors seem to balance each other well enough so that the respiratory parameters remain within a relatively narrow range. 
It appears that the opposite responses of the hemocyanin nolecule to salt and $\mathrm{PH}$ allow for a remarkable homeostasis of respiratory function in the unstable estuarine environment. 


\section{LITERATURE CITED}

Ballard, B. S. and W. Abbott (1969) Osmot1c accomnodation in Callinectes sapidus Rathbun. Comp. Biochem. Physiol. 29: 671-687.

Dehnel, P. A. (1960) Effect of temperature and salinity on the oxygen consumption of two Intertidal crabs. B10. Bull., 118: 215-249.

Fyhn, H. J., J. A. Petersen and R. Johansen (1972) Eco-phystological studies of an Intertidal crustacean. Pollicipes polymerus. (Cirripedia, Lepadomorpha). J. Exp. B101.. 57: 83-102.

Gerard, J. F. and R. Gilles (1972) The free anino acid pool in Callinectes sapidus (Rathbun) tissues and its role in the osmotic intraceilular regulation. 3. Exp. Mar. Biol. Ecol. 10: $125-136$.

Hagerman, I. (1970) The oxygen consumption of Crangon Vulgaris (Fabricius) (Crustacea, Natantia) In Relation To Salinity. Ophelia, 7: 283-292.

Hedgpeth, J. (1967) Ecological aspects of the Laguma Madre, a hypersaline estuary: pp. 408-419 in Estuaries (G.H. Lauff, ed.). Amer. Assoc. Adv. Sc1. Washington, D.C.

Hof fman, R. J. and C. P. Mangum (1970) The function of coelomic cell hemoglobin in the polychaete Glycera dibranchiata. Comp. Biochem. Physiol. 36: 211-228.

Laird, C. M. (1973) The effects of intrinste and environmental factors on the oxygen consumption of the blue crab, Callinectes sapldus Rathbun. M.A. Thesis. College of William and Mary, Hilliamsburg, Virginia.

Lance, J. (1965) Respiration and osmotic behavior of the copepod Acartia tonsa in diluted sea water. Comp. Blochem. Physiol. 14: 155-165.

Lartmer, J. L. and A. F. Rlggs (1964) Properties of hemocyanins. 1. The effect of calcium tons on the oxygen equilibrium of crayfish hemocyanin. Comp. Biochem. Phys1ol. 13: 35-46. 
Lynch, M. P., K. L. Webb and H. A. Van Engel (1973) Varlations in serum constituents of the blue crab Callinectes sapidus: chloride and osmotic concentration. Comp. Biochem. Physiol. 44: $719 \cdot 934$.

Mangum, C. P. (1976). The function of respiratory pigments in estuarine animals. 3rd Intern. symp. Estuarine Research Fed., Univ. Maryland Press, Washington, D. C. (In press).

Mangum, C. P. and L. M. Amende (1972) Blood osmotic concentration of the blue crab (Callinectes sapldus Rathbun) found in fresh water. Ches. Sci. 13: 318-320.

Mangum, C. P. and J. M. Shick (1972) The PH of body fluids of marine invertebrates. Comp. Blochem. Physiol. 42A: 693-698.

Pickett, S. H., A. F. Riggs and J. L. Larimer (1966) Lobster hemocyanin: properties of the ninimum functional subunit and of aggregates. Science 151: 1005-1007.

Schoffeniels, E. and R. Gilles (1970) Osmoregulation Inaquatic arthropods. In, Chemical Zoology, edited by M. Florkin and B. Scheer, Academic Press, New York and London, Vol. 5, Part A, pp. 255-286.

Siebers, D., C. Lucu, K. R. Sperling and K. Eberlein (1972) Kinetics of osmoregulation in the crab Carcinus meanas. Maŕ. Biol. 17: $291-303$.

Spoek, G. L. (1967) The influence of salts on the binding of oxygen by the haemocyanin of the lobster Homarus gammarus: Neth. Soc. Phys1ol. Pharm. Proced. 105: 503-504.

Truchot, J. P. (1973) Fixation et transport de $1^{\prime}$ oxygene par le sang de Carcinus meanas: varlations en rapport avec diverse conditions de temperature et de salinite. Neth. J. Sea Res. I: $482-495$. 


\section{VITA}

\section{Alan Lawson Welland}

Born In New York City March 24, 1950. Graduated from Columbia Preparatory School in that city, May, 1968. B.S. degree, State University of New York at Stonybrook, 1972. M.A. candidate, College of William and Mary, 1972-76, where he was a graduate teachIng assistant in the Department of Blology.

In September, 1974, the author entered the Medical College of Virginia as a first year student in the School of Dentistry. Awarded a research fellowship in 1976 to investigate the possible role of immunologic phenomena in the etiology of perfodontal disease. 